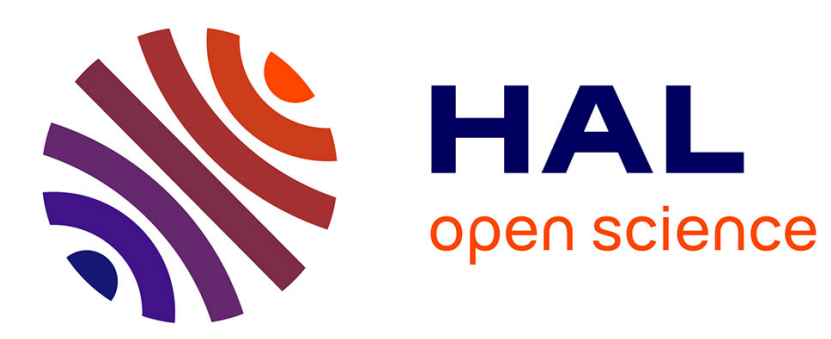

\title{
'The New Global Politics of Religion': religious harmony, public order, and securitisation in the post-colony
}

Iza Hussin

\section{To cite this version:}

Iza Hussin. 'The New Global Politics of Religion': religious harmony, public order, and securitisation in the post-colony. Journal of Religious and Political Practice, 2017, The Politics of Religious Freedom in the Asia-Pacific, 4 (1), pp.93-106. 10.1080/20566093.2017.1393173 . halshs-03158066

\section{HAL Id: halshs-03158066 \\ https://shs.hal.science/halshs-03158066}

Submitted on 3 Mar 2021

HAL is a multi-disciplinary open access archive for the deposit and dissemination of scientific research documents, whether they are published or not. The documents may come from teaching and research institutions in France or abroad, or from public or private research centers.
L'archive ouverte pluridisciplinaire HAL, est destinée au dépôt et à la diffusion de documents scientifiques de niveau recherche, publiés ou non, émanant des établissements d'enseignement et de recherche français ou étrangers, des laboratoires publics ou privés. 
'The New Global Politics of Religion': Religious Harmony, Public Order, and Securitisation in the Post-colony

Iza Hussin

Department of Politics and International Studies, University of Cambridge, Cambridge, United Kingdom

Ih298@cam.ac.uk

University Lecturer in Asian Politics, University of Cambridge; Mohamed Noah Fellow, Pembroke College. 


\section{'The New Global Politics of Religion': Religious Harmony, Public Order, Securitisation in the Post-colony}

This article explores key concepts in legal reasoning on the issue of 'religious harmony' in Malaysia. It argues that the concept of religious harmony belongs to the realm of public order, and public order is indexed to the legal logic of internal security. In Malaysian legal reasoning, the genealogy of these concepts runs through India and the United Kingdom. Arguments for religious freedom based upon normative commitments to liberal rights do not take into account the institutional and legal logic of internal security, within which toleration has different stakes and meanings. When resources are deployed to support the state governance of religion in service of international security concerns, they further consolidate the confluence of internal security and religious harmony, often at the expense of religious minorities. Through a tracing of the reasoning and references of judges and litigants in a series of judgements on the uses of the word 'Allah' by Christians in Malaysia, this article details a post-colonial genealogy of religious harmony through concerns not for toleration or liberty, but for order.

Keywords: religion; Malaysia; Islam; law; rights; security

\section{Introduction}

In her essay introducing this symposium, Elizabeth Hurd asks, "is there any reason to think twice about the notion that government should help produce tolerant religious subjects and discipline those who fail to conform to the state's political and religious orthodoxies?" (3) Hurd locates this question - to which her answer is an emphatic yes in the context of "religious governance," here and in Beyond Religious Freedom: The New Global Politics of Religion characterised in terms of national and global projects to enjoin "good religion," and deter "bad religion." The goodness of religion, in this ecosystem of concepts, inheres in its foreswearing of violence, its cultivation of "moderate" believers, its commitment to freedom of worship and belief under law. In this view, promoted globally by the United States in initiatives to enhance religious freedom and counter terror, but also adopted by a growing collectivity of states and 
organisations, the concepts of toleration, moderation, and freedom cluster together in a virtual and liberal cycle, and produce religious harmony. (Hurd 2015) Advocates of this view often also point to long-standing traditions of toleration and harmony in Asian societies that allow these visions to be read in indigenous vernaculars, histories to which we might return that do not depend upon Western liberal imports. ${ }^{1}$

However, religious harmony has a complex history, balanced between commitments to the provision of rights and requirements for the provision of order. Particularly in states which inherited their legal systems from the British, including India, Singapore, and Malaysia, the post-colonial genealogy of the concept of religious harmony passes through concerns for public order, and has been institutionalised in law through mechanisms aimed at the preservation of internal security. Arguments for religious freedom based upon normative commitments to liberal rights do not take into account the institutional and legal logic of internal security, within which toleration has different stakes and meanings. When resources are deployed to support the state governance of religion in service of US security concerns, they further consolidate the confluence of internal security and religious harmony, often at the expense of religious minorities. Through a tracing of the reasoning and references of judges and litigants in a

\footnotetext{
${ }^{1}$ See Alfred Stepan, "Religion, Democracy, and the "Twin Tolerations, "Journal of Democracy
} 11.4 (2000) 37-57; for a range of perspectives on the question, also see: Robert Hefner, "The Study of Religious Freedom in Indonesia," The Review of Faith \& International Affairs Vol. 11 , Iss. 2, 2013; Chandra Muzaffar and Sulak Sivaraksa (1999), Alternative politics for Asia: A Buddhist-Muslim Dialogue, International Movement for a Just World (Malaysia); Ziauddin Sardar, "Tolerance v terror: even though extremism has taken root in Indonesia, Malaysia and the Philippines, their long tradition of moderate Islam offers hope," New Statesman, July 21, 2008, Vol.137(4906), p.35(1) 
series of cases on the uses of the word 'Allah' by Catholics in Malaysia, this article details a conceptual genealogy of religious harmony through concerns not for toleration or liberty, but for order. ${ }^{2}$ The "new global politics of religion" (Hurd 2015) features the entanglement of religious freedom with religious harmony, through dynamics of securitisation.

\section{Titular Roman Catholic Archbishop of Kuala Lumpur v. the Minister of Home} Affairs and the Government of Malaysia:

Herald - The Catholic Weekly is a print newspaper affiliated with the Roman Catholic church in Malaysia, published by the Archbishop of Kuala Lumpur on behalf of the Catholic Bishops of Peninsular Malaysia. Under the 1984 Printing Presses and Publications Act, all printing presses require a license to operate, and this license must be renewed annually. The license is granted by the Minister of Home Affairs, to whom the Act gives broad discretion to grant and revoke permits to print and publish newspapers, and to impose conditions upon such permits. ${ }^{3}$ On the $30^{\text {th }}$ of December 2008, the publisher of the Herald received notice from the Ministry of Home Affairs that the newspaper's permit to publish for the year 2009 was granted:

\section{APPROVAL OF APPLICATION PUBLICATION PERMIT \\ 2. It is a pleasure to inform you that your application has been granted with the conditions listed below:}

\footnotetext{
${ }^{2}$ Portions of the 'Allah' cases have been discussed in Hussin, The Politics of Islamic Law: Local Elites, Colonial Authority and the Making of the Muslim State, Chicago 2016. This article is part of a larger comparative project on religious harmony and internal security (Hussin, forthcoming.)

${ }^{3}$ Printing Presses and Publications Act 1984 (Act 301).
} 
i) Publication in the Malay language is not permitted until the court has ruled in the case regarding the use of the word "ALLAH."

ii) This publication may only be sold in church.

iii) The cover page of the magazine must display "Consumption only for members of the Christian religion." ${ }^{4}$

The Archbishop responded to these restrictions in a letter seeking reconsideration, arguing that "We are...advised and verily believe that this condition constitutes a serious violation of our constitutional freedom of expression and speech," and of the rights of citizens to express themselves in the national language, Bahasa Malaysia (Malay). The Ministry responded on the $7^{\text {th }}$ of January 2009:
APPROVAL OF APPLICATION PUBLICATION PERMIT
2. For your information, this Section has reconsidered the approval of the publication permit... and the decision is as follows:
i) The application to publish in Malay has been approved, nevertheless, the use of the word "ALLAH" is prohibited until the court has made a decision on the issue. ii) On the cover page of this publication shall be printed the word "RESTRICTED" that carries the meaning that this publication is limited for distribution in church and to Christian worshippers only. ${ }^{5}$

The Archbishop, acting as the publisher of the Herald, filed for judicial review by the High Court of Malaya in Kuala Lumpur, seeking removal of the first condition, and naming the Minister for Home Affairs and the Government of Malaysia as respondents. The application cited Article 3(1) of the Federal Constitution to argue that "the Applicant has the constitutional right to use the word "Allah" in "Herald - The Catholic

\footnotetext{
${ }^{4}$ High Court of Malaya, Application for Judicial Review R1-25-28-2009, Judgement of Arifin Zakaria (CJ), 5. Author's translation.

${ }^{5}$ Ibid, 6.
} 
Weekly" in the exercise of the Applicant's right that religions other than Islam may be practiced in peace and harmony in any part of the Federation." Further, the argument cited Article 10 as providing the right to freedom of speech and expression, Article 11 providing freedom of religion, "which includes the right to manage its own religious affairs," and Article 12, granting "the Applicant's right in respect of instruction and education of the Catholic congregation in the Christian religion.” The application sought a declaration that the Ministry's prohibition was beyond the scope of the Printing Presses and Publications Act, determinations as to the constitutional rights cited, and a decision "that the word "Allah" is not exclusive to the religion of Islam."

The Judge, Lau Bee Lan, summarised the Minister for Home Affairs' defense of the prohibition of the use of "Allah" as such: firstly, the prohibition only extended to the use of the word in print versions of the newspaper, "intended to ensure the prevention of religious confusion (kekeliruan agama) that could threaten public safety and peace and raise religious sensitivities (sensitiviti keagamaan) in this State." (9) Further, the Minister argued that the prohibition was based upon "Allah" as the referent for "the One God for the followers of the religion of Islam as revealed in Al-Quran, Surah AlIkhlas," as sanctioned by the Federation, and as used "among Malaysia's citizens" (kalangan rakyat Malaysia). (11) Following from that argument, the Minister concluded that his discretion in setting conditions was therefore warranted, particularly in view of guidelines "that clearly provide that publications of religions other than Islam are prohibited from using terms specific to the religion of Islam."(10) Further, "there exist alternative words that the Applicant can use because from the perspective of translation, it is clear that there is no official dictionary that defines the word "God" as Allah in the

\footnotetext{
${ }^{6}$ High Court of Malaya, Judgement of Datuk Lau Bee Lan (J), 31.12.2009, 4-5.
} 
Malay language." (10) The Archbishop refuted each of these arguments above, and the Judge ultimately agreed, ruling the prohibition both illegal and unconstitutional.

The judgement goes on to address implications of constitutional provisions for Islam as the state religion, and to regulate and prohibit the propagation of religions other than Islam amongst Muslims (Article 11(4)). In the 1980s, the Malaysian government had prohibited the use and possession of Malay-language Bibles - specifically the Bahasa Indonesia Bible, referred to as 'Al-Kitab' - except to Christians, in churches. It also determined that the words "Allah," "Kaabah," "Baitullah," and "Solat" were exclusive to Islam, "and cannot be used in published materials of other religions save to explain concepts pertaining to the religion of Islam." " Each of these steps were justified through appeals to internal security, and largely enforced through the Printing Presses and Publications Act of 1984, overseen by the Ministry of Internal Security. (21) The Judge commented, "I find there is merit in...(the) argument that the Court ought to take judicial notice that in other Muslim countries even in the Middle East where the Muslim and the Christian communities together use the word "Allah," yet one hardly hear (sic) of any confusion arising...I am incline (sic) to agree that the Court has to consider the question of "avoidance of confusion as a ground very cautiously so as to obviate a situation where a mere confusion of certain persons within a religious group can strip the constitutional right of another religious group... and to render such guaranteed right as illusory." (45)

\footnotetext{
${ }^{7}$ Ibid, 20. 'Al-Kitab' is Arabic, translating to "The Book," "Kaabah" refers to the cube-shaped building within the Sacred Mosque in Mecca to which Muslim orient the direction of ritual prayer; "Baitullah" is Arabic for 'house of God,' also a reference to the Kaabah; "Solat" is ritual prayer.
} 
The decision was overturned in 2013, during which the Court of Appeal, ruling in favour of the Minister for Home Affairs, the Government of Malaysia, and other appellants, including the Islamic Religious Councils of six states and the Malaysian Chinese Muslim Association, also ruled against the High Court's finding on the constitutional right to use the word "Allah." The Court noted that since 1998, the Herald had been under notice by the Ministry of Home Affairs to comply with these prohibitions, citing eight letters sent between 1998 and the prohibition notice letter in 2007. ${ }^{8}$ These letters also made arguments about the need to avoid confusion: "the Government is responsible for avoiding confusion within a multi-religious society, which left (without intervention) can threaten public safety and peace...As a religious institution that has many worshippers from amongst multi-racial Malaysian citizens, your party too have a similar responsibility to preserve the religious harmony of Malaysian society."9

In his decision, Judge Mohamed Apandi bin Ali further argued that Article 3(1), "Islam is the religion of the Federation; but other religions may be practiced in peace and harmony in any part of the Federation," must be understood in terms of its history. It was "a by-product of the social contract entered into by our founding fathers," (28) within which context the phrase "in peace and harmony" was intended to protect Islam as the religion of the Federation. In addition, it was to "insulate against any threat faced or any possible and probably threat to the religion of Islam. It is also my judgment that

\footnotetext{
${ }^{8}$ Judgement of Mohamed Apandi bin Ali (JCA), 14.10.13, 9.

${ }^{9}$ Ibid, author's translation.
} 
the most possible and probable threat to Islam, in the context of this country, is the propagation of other religion (sic) to the followers of Islam." 10

The Allah case makes reference to multiple Malaysian histories of the principles of religious freedom, religious harmony, and freedom of expression. The Archbishop and the Herald drew too from a long history of Christianity, pointing to " 15 centuries" in which Arabic-speaking Christians and Muslims "have been using the word "Allah in reference to the One God," "several centuries" in which Christians in the region have been Malay speakers, "generations" of use by "the Bahasa Malaysia speaking Christian natives of Peninsular Malaysia, Sarawak and Sabah." "Arguments on behalf of the state drew their evidence from a more restricted timeline: negotiations prior to Malaysian independence from Britain, debates in the 1970s and 1980s about the place and significance of Islam as the religion of the Federation, and increasing anxiety in more recent years about evangelical Christianity since the late 1990s, marked in part by increasing pressure by the government to enforce limitations upon the Herald. The narrative of the Herald was that of indigeneity and citizenship; the narrative of the state was consistently that of public order, keyed to the preservation of Islam.

\section{Governing Lived and Expert Religion}

Beyond Religious Freedom poses a tripartite heuristic for exploring the intersections and co-productions of politics, law and religion: "expert, lived and governed religion." (Hurd, this issue, 5) Here, in the published and cited accounts of court cases, licensing procedures, and judicial reasoning, we see governed religion: not

\footnotetext{
${ }^{10}$ Ibid, 29. The Judge followed this with reference to Article 11(4), regulating proselytisation amongst Muslims.

${ }^{11}$ High Court of Malaya, Judgement of Datuk Lau Bee Lan (J), 31.12.2009, 15-17.
} 
only in the regulatory aspect of the state and its administration, but in the making of legible scripts of religion in which a newspaper, its publisher, the titular head of a national church, and the representative of a religious 'community' are all the same person. This person becomes the interlocutor with whom the state will speak, and the one responsible for the speech and practices of an entire faith community, and its adherence to the law. We also see, in these cases, attempts to define both Islam and Christianity in terms of sacred text, representative and authoritative practice, and singular orientations to meaning, producing the "politics of representative "faith communities."” (Hurd, this issue, 13)

The Allah case demonstrates one iteration of the entanglements that are both possible and likely between governed, expert and practised religion; the effort to govern religion requires a mastery over the representation of its practices, and of expertise on its meanings and history. In support of the public order basis of the decision, the Judge drew in quotes from legal scholars, including the constitutional scholar Andrew Harding: "the restriction of proselytism has more to do with the preservation of public order than with religious priority." (30) ${ }^{12}$ Here, in the words of the judge in the Allah appeal, was also an interpretive effort to define authoritative and essential practice through reference to sacred texts:

From a quick research on the history of the language of the Bible, it is clear that the word "Allah" does not appear even once as the name of God...in the Hebrew

\footnotetext{
${ }^{12}$ Harding has refuted this reading of his argument, in "Language, Religion and the Law: A Brief Comment on the Court of Appeal's Judgment in the Case of the Titular Roman Catholic Archbiship of Kuala Lumpur," Praxis, Oct.-Dec. 2013, 12-14. See also: Jaclyn Neo, "What's in a Name? Malaysia's 'Allah' controversy and the judicial intertwining of Islam with ethnicity," I•CON (2014), Vol. 12 No. 3, 751-768.
} 
scriptures. The name "Allah" does not appear, even once in either the Old or New Testament. There is no such word at all in the Greek New Testament. In the Bible world, God has always been known as Yahweh... That being the historical fact it can be concluded that the word or name Allah is not an integral part of the faith and practice of Christianity, in particular that of the Roman Catholic Church. ${ }^{13}$

Governed religion does not, in this case and in many others beyond Malaysia, deal with individual believers; it deals with communities and their recognised representatives and texts. As such, the effort to govern religion is crucially centred on the interpretation of these texts and their relationship to community practice. This too is a practice that harkens back at least to the colonial period. In Malaya, India and many colonial states colonial judges and officials worked to define local religion through prioritising sacred text over practice, interpreting religion through a selection of texts, and then reifying those textual practices as authoritative. ${ }^{14}$ The efforts of Malaysian judges to do the same with regard to Christianity in the contemporary period may have less to do with a colonial impetus, than with learned traditions of law in which the work of the judiciary has, since the coming of British judges to India in the $1760 \mathrm{~s}$, been to select, define and authorise amongst the practices of its subject populations. (Hussin 2017b) As the next section shows, India remains an important source of law for Malaysian courts; yet the use of Indian and British citations in the Allah cases provided another level of

13 "Menteri Dalam Negeri \& Ors v Titular Roman Catholic Archbishop of Kuala Lumpur," Civil Appeal No W-01-1-2010, 38-39. Two other judges, Judge Aziz and Judge Zawawi Salleh, also sought to frame their concurring decisions in terms of avoiding confusion, including amongst Christians themselves. See: Joshua Neoh, “The Name of God on Trial: Narratives of law, religion and state in Malaysia," Law Text Culture, 18, 2014, 198-220, 215. ${ }^{14}$ Hussin 2016. 
interpretive construction on the relationship between religious harmony, public order, and national security.

\section{'Law and Order', 'Public Order', and 'the Security of the State'}

In the Allah judgement at the appellate level, Judge Mohamed Apandi bin Ali argued that the restriction of fundamental liberties is justified in the face of "potential disruption of the even tempo of the community."(33) The judge cited Kishori Mohan Bera v The State of West Bengal [1972 (3) SCC 845], in which the Supreme Court of India made distinctions amongst the concepts of "law and order," "public order," and "the security of the state." ${ }^{15}$ In Kishori Mohan, a case involving assault, intent to kill, and revolt against the Indian state, the suspension of ordinary recourse to due process was judged to be unwarranted in part because no distinction was made between "the maintenance of public order," and "the security of the state." The Supreme Court referred to precedents establishing the distinction between law and order, public order, and the security of the state, in terms of concentric and diminishing circles: "Every infraction of law must necessarily affect order, but an act affecting law and order may not necessarily also affect the public order. Likewise, an act may affect the public order, but not necessarily the security of the State." 16 The Court argued that restrictions of rights such as habeas corpus should be undertaken "with extreme care and scrupulously within the bounds laid down in such a law.”(4)

Having discussed the distinction between law and order, public order, and the security of the state in the Allah appeal, Judge Mohamed Apandi then referred to these same concepts again in another case drawn from the Supreme Court of India, Collector

\footnotetext{
${ }^{15}$ AIR 1972 SC 1749, (1972) 3 SCC 845, 1973 (5) UJ 98 SC

${ }^{16}$ Ibid.
} 
and District Magistrate v S Sultan, quoting the principle that "it is the potentiality of the act to disturb the even tempo of life of the community which makes it prejudicial to the maintenance of the public order." ${ }^{17}$ Collector and District Magistrate $v$ S Sultan, a case from the 2000s involving assault with deadly weapons and explosives, again involved the legality of suspensions of habeas corpus. In raising the 'concentric circles' invoked in Kishori Mohan, the Supreme Court in this later Indian case sought to establish that the category of "public order is synonymous with public safety and tranquility...public order if disturbed, must lead to public disorder."(14)

For Judge Mohamed Apandi, the Allah case was neither merely an issue of law and order, nor of public order, but also one involving national security, therefore permitting the limitation of rights in law. His next citations moved to the British courts: $A, X$ and $Y v$. Secretary of State for the Home Department [2004] QB 335, $R v$. Secretary of State for the Home Department Ex P McQuillan [1995] 4 All E.R 400, and $R$ v. Secretary of State for the Home Department, ex parte Hosenball [1977] 3 All E.R 452. A, $\mathrm{X}$ and $\mathrm{Y}$ were foreign nationals arrested under suspicion of terrorism against the United Kingdom; McQuillan was a member of the Irish Republican Socialist Party subject to exclusion from the United Kingdom; Hosenball was a foreign national deported under suspicion of illegal espionage. The Malaysian judge's argument based on these citations was: "it is not for the court to probe for strong evidential proof of national security. It must be inferred that the Minister's decision, involving national security, is rational." (35)

Two striking patterns seem to emerge from these citations and the arguments they support in the Allah case: the first relates to the kinds of threats posed, and the

${ }^{17}$ AIR [2008] SC 2096 
second to the reasoning that locates the Allah case in the category of national security. The potentiality of threats to public order in Kishori Mohan and S Sultan involved armed violence against the public and the state; the latitude granted to the state in the UK cases involved terrorism, espionage, and Irish Republicanism. In contrast, the Allah case, in substance, involved Malaysian Christians and issues related to speech and worship; yet the concern regarding religious sensitivity, and the location of the case in the context of the Malaysian Printing Presses and Publications Act, making it a matter for the Minister for Home Affairs, places the issue under the logic of national security.

In this, the post-colonial legal systems of India and Malaysia not only owe their institutional makeup, their networks of training and cultures of judicial interpretation to the United Kingdom, they also continue to draw material and lessons from British courts and cases to address contemporary issues. When they do so, the institutional legacies of colonial law continue to shape the location of these issues in the law, and these locations then help determine the logic within which the issues will be deliberated, and the stakes attached to them. Of course, the ways in which judges have drawn on these legacies, and re-constructed their logics, also shows a great deal of leeway in interpretation. Additionally, the feedback loop between policy, society, political parties, and public debates is evident, as each controversy fuels a further sense of political urgency, and each policy move feeds further controversy. The Allah case arose in the midst of a series of high-profile and controversial legal battles over the conversion of Muslims to Christianity such as the Lina Joy case, thereby linking debates about the religious rights of Christian minorities in Malaysia to heightened anxieties about the religious identity of the Muslim majority.. (Hussin 2017b) In the section that follows, I discuss the effects of another, more recent, source of logics, law and state power: the international 'war on terror.' 


\section{National Security and the International War on Terror}

British colonial administrations in India, Malaya and elsewhere in the empire considered local religious 'sensitivities' to be a potential source of threat to the order of the colonial state. (Hussin 2016, 73) Public order delivered through the mechanism of internal security legislation and policy continued in this logic in post-colonial India and Malaysia. Under this logic, religious harmony is predicated upon a careful balancing between the requirements of the state for order, the demands of religious communities for freedom of practice, and the need for these practices not to overlap into the sensitivities of other religious communities. ${ }^{18}$ Whereas critics of the Court of Appeal judgement on the Allah case point to the overturning of the original decision as a symptom of the rise of Malay-Muslim nationalism, and to the interpretation of 'peace and harmony' as a limit condition for religious freedom, it may be important to also acknowledge how deeply institutionalised these logics have been in British and postcolonial common law. ${ }^{19}$

In terms of policy and politics, this genealogy is important because it indicates that the root causes of the securitisation of religious freedom lie in institutional legacies, in legal culture and history, as well as in rising nationalism. In terms of analytic utility, this genealogy matters because it helps makes sense of the placement of otherwise quite tangential issues - freedom of worship, freedom of expression, violent extremism, the

\footnotetext{
${ }^{18}$ The constitutional provisions relating to religious freedom (Art 3(1), 11(1), 11(4) and 11(5)) couch the right to freedom of worship explicitly within the limits of public order.

${ }^{19}$ See Hussin 2016, 240, 253; notably, this institutionalisation was promoted by legal and political actors in conversation and collaboration within the British post-colony, such as in the work of the Reid Commission that produced the Federal Constitution of Malaya.. Also, Hussin, forthcoming, on established religion and internal security.
} 
security of the state - into the same body of law-making and legal debate: internal security. Under this logic, what tend to be characterised as problems of religious freedom under human rights and international liberal advocacy, including by US agencies such as USAID and the State Department - limits on religious expression and worship, the policing of heterodox religious communities, and the treatment of religious minorities - are addressed within national legal systems as problems of internal security and public order.

Since 2001 in particular, along with increased US interest and investment in Muslim political and militant groups beyond the Middle East, there has been a growth in international support for increased monitoring, legislation, and control of Islam, under the overarching ambit of anti-terrorism. Increasingly, then, alongside lived, expert and governed religion, there is a growing circulation of international, securitised religion, emergent not just "through global advocacy for religious rights and freedoms," (Hurd this issue, 8) but through investment, alliance and policy-making through the security, intelligence and military capacities of the modern state and the international system.

The 2015 'International Religious Freedom Report' on Malaysia, released by the US State Department, in a section entitled 'US Government Policy,' reported that “in August the U.S. Special Envoy and Coordinator for Strategic Counterterrorism Communications met with government officials and civil society activists about the importance of religious freedom and its role in countering radicalization, as well as growing racial and religious intolerance in the country." ${ }^{20}$ The United Nations'

\footnotetext{
${ }^{20}$ United States Department of State, 'Malaysia 2015 International Religious Freedom Report,'
} 11. Available at: 
Secretary-General's Plan of Action to Prevent Violent Extremism lists the UN bodies

"working on issues relevant to preventing violent extremism," including:

the Counter-Terrorism Implementation Task Force and the United Nations Counter-Terrorism Centre, the Counter-Terrorism Committee Executive Directorate, the United Nations Development Programme, the Office of the United Nations High Commissioner for Human Rights, the United Nations Educational, Scientific and Cultural Organization, the United Nations Office on Drugs and Crime, the United Nations Alliance of Civilizations, the Department of Peacekeeping Operations of the Secretariat, the Peacebuilding Support Office and the United Nations Entity for Gender Equality and the Empowerment of Women (UN-Women), and my Envoy on Youth, as well as many other members of the United Nations family. ${ }^{21}$

The Plan of Action is "all-of-UN," broad-based, intended to be implemented nationally by all member states, and targetted not only at counter-terrorism, but at law, development, human rights, aid, etc, through the logic of 'prevention.' The Plan has been read as a response to narrower US military and security agenda in the years immediately after $9 / 11$, and this broader approach is in fact one the US itself has become keen to develop, in miltary and diplomatic programs. (Modirzadeh 2016) The UK's broad-based agenda, the 'Prevent strategy,' in fact sees non-violent extremism as a key target of its efforts, defining extremism as "vocal or active opposition to

http://www.state.gov/j/drl/rls/irf/religiousfreedom/index.htm?year=2015\&dlid=256119. Last accessed 25.3.2017.

${ }^{21}$ United Nations General Assembly A/70/674, Plan of Action to Prevent Violent Extremism: Report of the Secretary-General," 3. Available at: http://www.un.org/en/ga/search/view_doc.asp?symbol=A/70/674. Last accessed 25.3.2017. 
fundamental British values." 22 When used in the UK, it has been critiqued for providing sweeping and undefined powers of surveillance and enforcement, and requiring social service agencies, educational institutions, and local police to provide oversight on large areas of speech, assembly and organisation. When exported beyond the UK, through diplomacy, training and education programs, "the concept hasn't caught on with most western democracies, which remain focused on countering violent extremism; but it has been warmly received by non-democratic states, including some in the Gulf, which favour the sort of broad definitions that tar nonviolent dissidents with the same brush as violent ones." (Kinninmont 2016)

Malaysia has played a prominent and critical role in international efforts to counter violent extremist Islam: it is a member of the 'Global Coalition to Counter ISIL,' it is in close intelligence and policing cooperation with US efforts in the region, and it has passed a number of new laws aimed at preventing and countering terrorism. Malaysia participated in the 'Summit on Countering Violent Extremism (CVE)' at the White House in February 2015, and a number of other CVE events, and announced its founding of the Global Movement of Moderates, which also conducted a number of CVE events. The US 'Country Reports on Terrorism 2015 (Malaysia),' summarising the new legislation, noted that "the Malaysian Parliament passed the National Security Council Act, which gives the Prime Minister unchecked authority to wield martial-lawlike powers in any part of the country designated by the Prime Minister as a "security area." Similar powers are defined by the Malaysian constitution, but were previously

\footnotetext{
${ }^{22}$ HM Government, 'Prevent Strategy 2011,' https://www.gov.uk/government/uploads/system/uploads/attachment_data/file/97976/prevent -strategy-review.pdf. Last accessed 25.3.2017.
} 
reserved to the king." ${ }^{23}$ In October 2016, Malaysia announced the formation of a National Special Operations Force, a coordinated anti-terrorism first responder force; in the announcement, the Malaysian Prime Minister articulated this force as part of his National Blue Ocean Strategy, involving more than 80 government bodies in charge not only of security, but also youth and family, women, public service, entrepreneurship and education. ${ }^{24}$

Joseph Liow, writing about Malaysia and the 'securitisation' of Islam after 2001, points out that critics of the Malaysian response

have accused the Malaysian government of capitalizing on the alarmist atmosphere by tenuously connecting terrorists with political dissidents and the Islamist opposition, and by mobilizing state authority to detain and incarcerate "suspected terrorists" without trial under the auspices of its vast array of instruments of coercion. These critics have further argued that the war on terror and attendant concern for "threats" to "national security" have been employed to further legitimize the surveillance state to even greater extents. (Liow 2009, 151)

Critics of government eagerness to embrace anti-terrorism measures, in Malaysia, India, Pakistan, Singapore, the Philippines and beyond, have observed the deployment and timing of these measures to also enhance and legitimise government surveillance, police powers, and suspensions of law. ${ }^{25}$ Institutional legacies alone do not explain the

${ }^{23}$ United States Department of State, 'Country Reports on Terrorism 2015 (Malaysia).' Available at: http://www.state.gov/j/ct/rls/crt/2015/. Last accessed 25.3.2017.

24 ‘PM Launches NSOF To Act Swiftly Against Terrorist Threats,' Bernama News, 27.10.16. Available at: http://www.bernama.com/bernama/v8/newsindex.php?id=1296575; 'Malaysia's National Blue Ocean Strategy,' https://www.blueoceanstrategy.com/malaysianbos/safety-security/. Last accessed 25.3.2017.

${ }^{25}$ Kalhan et al 2006, Liow 2009, Rajah 2012. 
emergence or enforcement of law in particular times and places, but the deployment of international resources for combatting terrorism has fed into the confluence of religious freedom, religious harmony, public order, and national security, to a new and troubling extent.

Returning to the Allah judgements, the expressed desire of the courts to prevent 'confusion', to preserve the 'even tempo' of the nation, and to avoid the inciting of religious tensions, played out against the backdrop of characterisations of Islam as potentially violent, and of Muslims in Malaysia as vulnerable to extremist ideologies. Rather than a decision regarding the ability of Christian Malaysians to exercise their rights to freedom of religion, therefore, the courts and the state articulated a need to avoid even the potentiality of inter-religious tension. While the politics of religious freedom affect the conceptual categories of religion more broadly, the specific position of Islam in contemporary politics presents a range of ironic possibilities for Muslim states: anxious to promote their brand of Islam as 'good Islam,' their capacities for surveillance, discipline and legitimation depend to some extent upon the continued existence of 'bad Islam.'

\section{Conclusion}

Hurd argues that "to invoke religious rights or religious freedom is also to invoke the history of the category of religion.” $(2015,122)$ In Malaysia, as well as in many post-British colonial states such as India, Pakistan, and Singapore, the category of religion occupies two related locations within law: locations related to rights, such as freedom of worship, and locations related to order, such as religious harmony. As the Allah case indicates, under some circumstances, religious freedom has been made contingent upon religious harmony; the securitisation of religion, supported by 
ideological and material resources from external actors, further strengthens this contingency. Lived, expert, and governed religion, to different degrees and in different ways, is being reshaped by securitisation. These three arena are inextricable, yet securitisation weights some institutional, ideological and disciplinary relationships more than others, changing the stakes for legislated and outlaw religion, extending particular networks of knowledge and training, and significantly increasing the social, political and legal costs of challenging the state. As state anxieties over the incendiary capacities of religion increase, and as particular definitions of good and bad religion circulate through international and national politics, the need to more closely examine the relationship between religion as rights and religion as order will also become more pressing. These relationships inhere in legal and institutional histories, not simply in contemporary political currents, and their variations do not neatly conform to liberal/non-liberal, democratic/authoritarian, secular/non-secular binaries.

These are the new global politics of religion: global and international resources deployed to counter terror have contributed to the most extensive policy and legislative efforts to increase state oversight of religion in the post-colonial period. National governments and international bodies are re-defining religion, forging new relationships between religious communities and the state, and constructing new discourses on the connection between individual religiosity, group affiliation, and social and political life. However, this does not spell the inevitable seizure of control over religion - however defined - by the state. Despite recent and growing restrictions by administrative and legal institutions, the internal inconsistencies, struggles and dynamics of governed religion manage to remain visible. The state is not a unitary actor, nor is it fully in control of governed religion. (Hussin 2017a; Neoh 2014, 204-206) 
Approaches to the study of religion, law and politics that emphasise the tendency of state law, institutions and actors to produce outcomes that discipline state subjects provide important perspectives on the operations of language, politics and power in line with secular logics. Yet to the extent that they present an account of state power that is unitary, they overstate the degree to which states hold coherent views, manage the language and logic of state institutions and agents, and control the reception of their acts. In so doing, they may underplay the incoherence of secular logics and of state authority, when it may be precisely this incoherence that paves the way for new political and social possibilities. The Allah case, while it tracks the evolution of state oversight and the securitisation of religion in Malaysia, also reveals a varied and complex picture of the politics of religious freedom and religious harmony - in the evidence of continued resistance of the publishers of the Herald to bureaucratic demands for compliance as well as in the reluctance of the same administrative structure to force compliance; in some states of the Federation ruling some words exclusive to Muslims, and the work of the national government to attempt to regulate and even limit the range of these prohibitions; in dissents among senior judges on the nature and extent of the constitutional and administrative issues at stake before the courts; and perhaps most powerfully of all, in iterated and public debates about Islam and its relation to Malaysian citizenship. These too, at a different scale, in different locations, are part of the new global politics of religion.

\section{References}

Hurd, Elizabeth. 2015. Beyond Religious Freedom: The New Global Politics of Religion. Princeton: Princeton University Press. 
Hussin, Iza. 2017a. "Making Legibility Between Colony and Empire: Translation, Conflation, and the Making of the Muslim State." In The Many Hands of the State, edited by Ann Orloff and Kimberly Morgan. New York: Cambridge University Press.

--- 2017b. "Citing Gender: Constituting the Muslim woman in Malaysia," Cultural and Social History. Forthcoming.

Kalhan, Anil, Gerald Conroy, Mamta Kaushal, Sam Scott Miller, Jed S.. Rakoff. 2006. “Colonial Continuities: Human Rights, Terrorism, and Security Laws in India," Columbia Journal of Asian Law, 2006, Vol.20 (1), 93-235.

Kinninmont, Jane. “Britain's loose definition of extremism is stoking a global crackdown on dissent," The Guardian 23.9.2016. https://www.theguardian.com/commentisfree/2016/sep/23/britain-extremism-globaleffects?CMP=share_btn_link.

Liow, Joseph. 2009. Piety and Politics: Islamism in Contemporary Malaysia, London: Oxford University Press.

Modirzadeh, Naz. 2016. "If it's Broke, Don't Make it Worse: A Critique of the U.N. Secretary-General's Plan of Action to Prevent Violent Extremism," Lawfare blog 23.1.2016. https://www.lawfareblog.com/if-its-broke-dont-make-it-worse-critique-unsecretary-generals-plan-action-prevent-violent-extremism.

Neoh, Joshua. 2014.“The Name of God on Trial: Narratives of Law, Religion and State in Malaysia," Law Text Culture, 18, 198-220. 
Rajah, Jothie. 2012. Authoritarian Rule of Law: Legislation, Discourse and Legitimacy in Singapore, Cambridge: Cambridge University Press. 